\title{
DAMPAK EKSPEKTASI DAN VOLATILITAS HARGA PADI TERHADAP ALOKASI LAHAN TANAM PADI DI INDONESIA
}

\author{
Yanti Nurhayanti, Widyono Soetjipto \\ Program Pascasarjana Ilmu Ekonomi, Fakultas Ekonomi dan Bisnis \\ Universitas Indonesia Jl. Salemba Raya No.4, Jakarta 10430 \\ Email Korespondensi: ynurhayanti@gmail.com
}

Naskah Diterima: Desember 2016; Disetujui: April 2017

\begin{abstract}
This paper aims to look at the impact expectations and volatility of the price of rice and corn to the acreage of rice in Indonesia. It is expected that with this paper can contribute academically. BBy using a panel data in district paddy, period 2011-2015, empirically proven expectations rise in price rice may increase the acreage of paddy. The volatility of the price rice paddy decreased acreage of rice. By using a panel data in district paddy, period 2011-2015, empirically proven expectations rise in price rice may increase the acreage of paddy. The volatility of the price rice paddy decreased acreage of rice.y using a panel data in district paddy quarterly period 2011-2015, empirically proven expectations rise in price rice may increase the acreage of rice. Increase the volatility of the price rice can decrease allocation acreage of rice. The estimation results with SYS-GMM method showed any increase in price rice expectations $1 \%$ can improve the allocation of planting $0,2500 \%$. The volatility of rice can decrease $0,0051 \%$ acreage of rice ceteris paribus. While the increase volatility of corn prices can increase the allocation of land for planting rice 0,0049\% ceteris paribus. The estimation results also indicate that the allocation of land planting rice more responsive than planting corn land allocation to alter expectations and price volatility. Policy price /HPP for farmers are not guaranteed to improve the allocation of arable land rice in each planting season.
\end{abstract}

Key word : rice price, acreage of rice, price expectations, price volatility

JEL Classification : O11,O13, Q11, Q13

Abstrak: Makalah ini disusun dengan tujuan untuk melihat sejauh mana ekspektasi dan volatilitas harga gabah dan jagung mempengaruhi alokasi lahan tanam padi di Indonesia. Diharapkan dengan makalah ini dapat memberikan kontribusi secara akademik dalam dalam mengkaji sejauh mana ekspektasi dan volatilitas harga GKP mempengaruhi penyediaan padi melalui respon alokasi luas tanam padi. Dengan menggunakan data panel kabupaten sentra padi secara kuartal periode tahun 2011-2015, terbukti secara empiris kenaikan ekpektasi harga gabah dapat meningkatkan alokasi lahan tanam padi sedangkan volatilitas harga gabah menurunkan alokasi lahan tanam padi. Hasil estimasi dengan metode SYS-GMM menunjukkan setiap kenaikan ekspektasi harga gabah 1\% dapat meningkatkan alokasi tanam sebesar 0,25\% sedangkan volatilitas harga menurunkan alokasi lahan tanam padi sebesar 0,0051\% ceteris paribus. Sementara itu volatilitas harga jagung meningkatkan alokasi lahan tanam padi sebesar 0,0049\% ceteris paribus. Selain itu hasil estimasi menunjukan bahwa alokasi lahan tanam padi lebih responsif dibandingkan dengan alokasi lahan tanam jagung terhadap perubahan ekpektasi dan volatilitas harga. Kebijakan HPP GKP tingkat petani belum memberikan jaminan dalam meningkatkan alokasi lahan tanam padi pada setiap musim tanam.

Kata kunci: harga padi, alokasi tanam, ekspektasi harga output, volatilitas harga

Klasifikasi JEL: O11, O13, Q11, Q13 


\section{PENDAHULUAN}

Ketidakpastian harga output merupakan salah satu permasalahan yang selalu dihadapi petani. Ketidakpastian harga output terjadi karena adanya proses alami yang membutuhkan waktu sehingga pada saat panen terjadi, petani belum tentu mendapatkan harga output sesuai dengan yang diharapkan (Moschini \& Henessy, 1999). Ketidakpastian harga output akan semakin tidak pasti ketika terjadi volatilitas harga output. Oleh karena itu Moschini \& Henessy mengkaitkan volatilitas sebagai sumber penyebab ketidakpastian harga di sektor petanian. Dimana ketika volatilitas harga terjadi petani sulit untuk melakukan prediksi harga output pada periode kedepan. Padahal harga output merupakan salah satu faktor yang dapat mempengaruhi keputusan petani untuk berproduksi (FAO, 2011). Petani yang tidak mampu mengantisipasi volatilitas harga output dapat beralih pada komoditas lain atau sektor usaha lain yang mempunyai tingkat volatilitas harga yang lebih kecil dengan tingkat ekonomi yang lebih tinggi (Sandmo, 1971; Coyle, 1992; Moschini \& Henessy, 1999; Batra \& Ullah, 1974; Haille, Kalkuhl, \& Broun, 2015).

Implikasi ketidakpastian harga terhadap produksi hasil pertanian merupakan isu yang telah lama menjadi bahan perhatian akademisi dan pemangku kebijakan. Bagi akademisi isu ketidakpastian harga output masih menarik untuk diteliti karena dengan perkembangan waktu, terjadi pengembangan dan penyempurnaan metodologi. Salah satu permasalahan penting yang sering dibahas oleh akademisi adalah mekanisme dampak volatilitas harga output terhadap produksi dan bagaimana pendekatan ekspektasi harga output yang digunakan. Sementara itu bagi pemangku kebijakan isu ini penting, khususnya untuk melihat sejauh mana keterkaitan volatilitas harga output terhadap ketersediaan produksi pangan.
Informasi ini diperlukan oleh pemangku kebijakan sebagai deteksi dini dalam mengantisipasi gangguan hasil produksi serta perencanaan produksi pada periode ke depan (Haille, Kalkuhl, \& Broun, 2015).

Pentingnya peranan volatilitas harga output dalam menentukan produksi telah mendorong perkembangan model produksi di sektor pertanian. Diantaranya transmisi dampak volatilitas harga output terhadap output produksi melalui perubahan alokasi lahan tanam (Chavas \& Holt, 1990; Coyle, 1992; Lansink, 1999). Mengingat keputusan alokasi lahan tanam merupakan respon awal petani terhadap adanya ketidakpastian/volatilitas harga output, oleh karena itu pada studi-studi dengan isu volatilitas harga output terhadap produksi pangan, lebih banyak menggunakan variabel dependen alokasi lahan tanam daripada produksi (Misalnya: Chavas \& Holt, 1990; Coyle, 1992; Lansink, 1999; Lin, 1997; Krause, Lee, \& Koo, 1995; Haille, Kalkuhl, \& Braun, 2013). Selanjutnya jika tidak mempertimbangkan volatilitas harga output dalam model maka parameter estimasi akan bias (Adesina \& Brorsen, 1987; Antonovits \& Green, 1990; Krause, Lee, \& Koo, 1995).

Di Indonesia ketersediaan padi sebagai bahan pangan pokok masyarakat Indonesia diduga dipengaruhi oleh volatilitas harga gabah kering (GKP). Mengingat besaran volatilitas harga rata-rata nasional GKP pada kurun waktu 5 tahun terakhir berada di kisaran 5,3 -10,20\%1. Tingkat volatilitas harga GKP tersebut relatif tinggi di atas tingkat fluktuasi yang diharapkan pemerintah yaitu maksimal 5\% untuk komoditas padi (Kementerian Pertanian, 2015). Selain itu

1 Tingkat fluktuasi dihitung berdasarkan nilai koefisien variasi harga GKP yang bersumber dari data BPS. 
sebagian besar harga GKP di Indonesia ditetapkan oleh mekanisme pasar. Hal ini dapat dilihat dari harga pembelian GKP oleh pemerintah selalu di bawah harga pasar dan besaran pengadaan gabah/beras oleh pemerintah hanya sekitar $10 \%$ dari total produksi padi nasional. Dengan demikian, kondisi volatilitas harga GKP yang terjadi dikuatirkan akan mempengaruhi produksi padi di Indonesia.

Studi mengenai permintaan alokasi lahan tanam padi yang menyertakan faktor risiko harga/volatilitas harga output di Indonesia masih terbatas. Studi terdahulu lebih banyak membahas dampak volatilitas harga terhadap sisi konsumen daripada sisi produksi. Namun pada sisi produksi sudah diterapkan pada komoditas hortikultura yang dilakukan oleh Fariyanti et.al (2007). Fariyanti et.al (2007) melakukan studi perilaku ekonomi rumah tangga petani sayuran pada kondisi adanya risiko produksi dan risiko harga di Kecamatan Pangalengan Kabupaten Bandung. Hasil studinya menunjukkan volatilitas harga kentang memberikan dampak negatif terhadap alokasi areal tanam kentang dan begitu juga sebaliknya. Sejauh mana dampak volatilitas harga gabah sebagai risiko harga terhadap sisi produksi belum ada informasinya.

Berdasarkan kondisi diatas, muncul pertanyaan tentang bagaimana dampak ekspektasi harga dan volatilitas harga gabah terhadap alokasi luas lahan tanam padi di Indonesia? Untuk menjawab pertanyaan penelitian tersebut penulis melakukan penelitian dampak ekspektasi dan volatilitas harga GKP terhadap alokasi tanam padi di Indonesia dengan mengadopsi studi yang dilakukan oleh Haille, Kalkuhl, \& Braun (2013, 2015). Model empiris yang akan dibangun pada penelitian ini mempertimbangkan perkembangan studi terbaru, diantaranya pendekatan ekspektasi harga output terbaru, isu ekonometrika terbaru dengan menggunakan metode estimasi GMM, pergerakan volatilitas harga dan periode waktu yang dipantau lebih pendek untuk menangkap perubahan alokasi tanam pada setiap pergantian musim tanam.

Pada makalah ini mekanisme dampak ekpektasi dan volatilitas harga output terhadap alokasi lahan padi dibangun dari dua kerangka konseptual. Kerangka konseptual pertama berdasarkan model Nerlove Partial Adjustment. Dan kerangka konseptual kedua berdasarkan teori produksi pada kondisi harga tidak pasti (price uncertainty) yang dikembangkan oleh Coyle (1992). Berdasarkan pendekatan model Nerlove Partial Adjustment, penawaran produksi dapat diformulasi dari alokasi luas lahan yang dipengaruhi oleh lag respons. Sementara itu pendekatan model Coyle (1992) berdasarkan maksimisasi kepuasan ekspektasi profit petani terhadap alokasi lahan tanam.

Berdasarkan tinjauan literatur pendekatan ekspektasi harga output yang digunakan petani bersifat heterogen dalammenggunakan informasi untuk membuat keputusan produksi. Kondisi ini menimbulkan beragam pendekatan ekspektasi harga output, akibatnya dampak ekspektasi harga output akan beragam terhadap keputusan petani (Antonovits \& Green, 1990). Pendekatan ekpektasi harga output yang sering digunakan antara lain, naif ( (Ezekiel, 1938), adaptif (Nerlove, 1956), ekspektasi rasional (Muth, 1961), pendekatan futures prices (Gardner, 1976), dan pendekatan reduced form (Nickell, 1981). Pendekatan ekspektasi output secara naif dan adaptif mendapatkan kritikan dari beberapa akademisi karena bersifat back-looking. Dimana pada kenyataannya harga output bersifat dinamis sehingga diperlukan pendekatan yang lebih bersifat forward-looking akan tetapi tidak efisien digunakan karena dalam pelaksanaannya memerlukan biaya dan sulit untuk diterapkan 
(Orazem \& Minanowski, 1994). Begitu juga penggunaan harga futures yang menjadi ambigu ketika petani tidak mempunyai akses pada pasar komoditi berjangka. Orazem \& Minanowski (1994) menyarankan pendekatan ekspektasi harga output lebih baik menggunakan harga aktual pada musim panen periode sebelumnya.

Pada makalah ini penulis akan menggunakan data harga output aktual menjelang musim tanam sebagai dasar dalam menentukan ekspektasi harga output. Hal ini berdasarkan studi terbaru oleh Haile, Kalkuhl, \& Usman (2015) yang menggunakan data survei terhadap petani di 7 wilayah di Ethiopia. Hasil survei menunjukkan bahwa petani cenderung menggunakan pendekatan naif dan adaptif daripada ekspektasi rasional atau harga futures. Berdasarkan beberapa model spesifikasi yang dibuat oleh oleh Haile, Kalkuhl, \& Usman (2015) menunjukkan bahwa harga aktual menjelang musim tanam merupakan better explanatory power daripada harga musim panen periode sebelumnya. Kemudahan informasi harga dan perkembangan alat komunikasi saat ini mendorong petani menggunakan informasi data terbaru yakni data aktual menjelang musim tanam sebagai dasar dalam menentukan ekspektasi harga output daripada harga aktual musim panen periode sebelumnya. Begitu juga perkembangan alat komunikasi di Indonesia sangat pesat, kemudahan informasi harga yang diterima petani semakin cepat.

Selain itu, secara simultan penelitian ini akan melibatkan alokasi lahan tanam jagung sebagai komoditas subtitusi dari padi. Hal ini untuk menunjukkan adanya peralihan komoditas sesuai dengan kerangka teori yang dikemukakan oleh Coyle (1992). Untuk itu maka data luas lahan yang digunakan dalam penelitian ini merupakan luas lahan yang digunakan untuk sawah padi total padi irigasi dan non irigasi yang memungkinkan dapat ditanam untuk kedua komoditas tersebut. Dengan mengikuti pengukuran alokasi lahan tanam padi, pengukuran alokasi lahan tanam jagung juga diukur pada periode maksimum yang sama untuk setiap subround musim tanam padi.

Penelitian ini bertujuan untuk melakukan estimasi sejauh mana ekspektasi harga dan volatilitas harga GKP memberikan dampak terhadap alokasi tanam padi di Indonesia terutama pada periode jangka pendek. Diharapkan dengan penelitian ini dapat memberikan kontribusi secara akademik dalam rangka pengembangan ilmu pengetahuan dan dapat menjadi referensi dalam mengkaji sejauh mana ekspektasi dan volatilitas harga GKP mempengaruhi penyediaan pangan melalui perilaku alokasi luas tanam padi.

\section{METODE PENELITIAN}

Pada penelitian ini, proxy ekspektasi harga output yang akan digunakan mengikuti studi yang dilakukan oleh Haille, Kalkuhl, \& Braun (2013) yaitu pendekatan harga aktual GKP menjelang musim tanam. Dalam hal ini petani bersifat perfect foresight dalam berekspektasi, yakni asumsi harga menjelang tanam akan sama dengan harga GKP yang akan diterima pada saat panen mendatang. Informasi terbaru harga aktual sebelum proses tanam atau satu bulan menjelang tanam dipandang lebih mendekati harga panen yang akan datang dibandingkan dengan menggunakan harga aktual panen pada musim tanam sebelumnya.

Untuk itu diperlukan kalender tanam untuk mengetahui pada bulan apa petani melakukan penanaman untuk setiap kabupaten. Bulan tanam yang akan dijadikan acuan untuk menghitung ekspektasi harga output merupakan periode bulan periode bulan yang mempunyai alokasi luas lahan tanam padi nilai maksimum pada 
setiap subround. Misalnya pada musim tanam/subround ke I (MH1) yang terjadi pada periode bulan Januari - April, jika alokasi tanam padi maksimum terjadi pada bulan Februari maka harga aktual gabah pada bulan Januari menjadi harga ekspektasi gabah. Begitu juga pada bulan tanam yang sama, harga jagung aktual di tingkat petani menjadi harga ekspektasi jagung.

Sementara itu fokus utama lainnya dalam penelitian ini adalah menangkap dampak risiko harga melalui volatilitas harga output. Perhitungan volatilitas yang akan digunakan mengikuti studi yang dilakukan Haile, Kalkuhl, \& Broun (2013) berdasarkan perhitungan yang dilakukan oleh Gilbert \& Morgan (2010) yaitu standar deviasi dari logaritma harga output pada level first diiference selama 12 bulan sebelum masa tanam. Misalkan jika bulan tanam Februari maka volatilitas harga output adalah standar deviasi logaritma harga output pada level first difference selama 12 bulan sebelum panen yakni Maret tahun sebelumnya sampai dengan Februari.

Persamaan empiris alokasi tanam padi kabupaten $j$ pada periode $t$ yang akan digunakan pada penelitian ini mengadopsi dari Haille, Kalkuhl, \& Braun (2013) yaitu persamaan logaritma sehingga semua variabel yang terlibat dalam bentuk logaritma kecuali variabel volatilitas. Pada penelitian ini penulis menggunakan alokasi tanam di level agregat kabupaten sentra padi, dengan pertimbangan kabupaten sentra padi yang terpilih merupakan daerah yang komoditas padi sebagai komoditi utama dan jagung sebagai komoditas utama ke 2 setelah padi. Lebih spesifik model spesifikasi estimasi adalah sebagai :

$$
\begin{aligned}
\ln A_{i j t}=\alpha \ln & \left(A_{i j t-1)}+\beta_{1} \operatorname{Ln}\left(E\left(p_{i j t}\right)\right)+\beta_{2} \operatorname{Ln}\left(E\left(p_{i j t}\right)\right)+\delta_{1} \Omega_{i j t}+\delta_{2} \Omega_{i j t}+\theta_{1} \operatorname{Ln}\left(w_{1 j t}\right)\right. \\
& +\theta_{2} \operatorname{Ln}\left(w_{2 j t}\right)+\theta_{3} \operatorname{Ln}\left(w_{3 j t}\right)+\rho_{1} H P P_{i j t}+\rho_{2} \mathrm{TT}_{i j t}+\rho_{3} \mathrm{Pddk}_{i j t}+\eta_{i t}+k_{i j}+\varepsilon_{i j t}
\end{aligned}
$$

$\beta_{1}, \delta_{2}, \rho_{1}, \rho_{2},>0, \beta_{2}, \delta_{1}, \theta_{1}, \theta_{2}, \theta_{3,} \rho_{3}<0$

dimana $A_{i j t}$ merupakan alokasi luas tanam komoditas i di kabupaten j pada periode ke-t, $A_{i j t-1}$ merupakan lag luas tanam komoditas i di kabupaten j pada periode ke-t, $E\left(p_{i j t}\right)$ merupakan ekspektasi harga output untuk komoditas ke i pada kabupaten ke j pada periode ke-t, $\Omega_{i j t}$ merupakan volatilitas harga output komoditas i di kabupaten $\mathrm{j}$ pada periode ke-t, $W_{1 j t}$ upah tenaga kerja, $W_{2 j t}$ input harga eceran tertinggi pupuk urea bersubsidi, $W_{3 j t}$ adalah input harga eceran tertinggi benih bersubsidi, $H P P_{j t}$ merupakan Kebijakan Harga Pembelian Pemerintah (HPP) GKP tingkat petani, $\mathrm{T} T_{j t}$ Total luas lahan sawah irigasi dan non irigasi, $\operatorname{Pdd} k_{j t}$ merupakan kepadatan penduduk, $\eta_{i t}$ efek fixed antar waktu, $k_{i j}$ merupakan efek fixed antar kabupaten, $\varepsilon_{i j t}$ error dan i sama dengan 1,2 menunjukan komoditas padi dan jagung.

Penelitian yang melibatkan variabel ekspektasi harga dan volatilitas tidak cukup dengan menggunakan data cross section karena perlu dilakukan observasi perilaku unit penelitian pada berbagai periode waktu. Data panel yang merupakan gabungan antara data cross section dan time series lebih efisien dalam mempelajari perubahan dinamis. Data panel dapat mendeteksi dan mengukur pengaruh yang tidak terobservasi pada data cross section dan time 
series, dan meminimalisasi estimasi yang bersifat bias (Shina \& Setiawan, 2015). Untuk itu pada penelitian akan menggunakan data panel selama periode waktu 5 tahun. Dimana unit analisis pada studi ini adalah tingkat kabupaten pada provinsi sentra padi yang meliputi N=119 kabupaten. Periode waktu data yang digunakan selama $\mathrm{T}=15$ musim tanam pada periode tahun 2011-2015.

Adapun sumber data yang digunakan berasal dari berbagai sumber data. Data luas lahan tanam padi dan jagung bersumber dari data Percepatan Penyediaan Data (PPD) Tanaman Pangan Kementerian Pertanian yang berkerjasama dengan Badan Pusat Statistik (BPS). Data harga padi dan jagung berdasarkan data Statistisk Harga Produsen Badan Pusat Statistik tahun 2011-2015 dan data pemantauan harga pangan panel BKP tingkat produsen, Kementerian Pertanian. Data harga input produksi upah tenaga kerja berdasarkan Statistik Upah Buruh Tani 2011-2015 BPS. Data harga input produksi pupuk urea berdasarkan Permentan Kebutuhan dan Harga Eceran Tertinggi Pupuk anggaran 2011-2015. Data harga input produksi benih berdasakan Permentan Pedoman Subsidi Benih tahun anggaran 2011, 2013 dan 2015. Data Harga Pembelian Pemerintah GKP tingkat petani bersumber Badan Ketahanan Pangan Kementerian Pertanian. Data jumlah penduduk bersumber dari data kependudukan tahun 2011-2015, Badan Pusat Statistik. Data Total Lahan Sawah Padi berdasarkan data Statistik Luas Lahan Menurut Penggunaannya tahun 2011-2015, Badan Pusat Statistik.

Pada penelitian ini menggunakan model regresi data panel dinamis yang melibatkan lag variabel dependen alokasi luas tanam sebagai variable dependen. Metode empiris yang digunakan adalah Generalized Method of Moments
GMM) yang merupakan penyempurnaan dari metode Instrumental Variable (IV) untuk menghasilkan penduga parameter yang tidak bias, konsisten dan effisien. (Anderson \& Hsiao, 1982; Arrelano \& Bond, 1991; Haille, Kalkuhl, \& Broun, 2015). Terdapat dua jenis metode estimasi dengan kerangka GMM, yaitu (1) First-Difference GMM (AB-GMM) dan (2) System GMM (SYSGMM). Pada prosedur estimasi AB-GMM dilakukan transformasi first difference tanpa variabel independen untuk memperoleh instrumen first difference yang valid sedangkan SYS-GMM untuk memperoleh variabel instrument first difference dan level.

Beberapa uji statistik yang dilakukan untuk mengetahui konsistensi estimator dari GMM yang dihasilkan (Arrelano \& Bond, 1991). Pertama, uji statistik Arellano-Bond untuk menguji autokorelasi pada level data harga output. Titik uji statistik Arellano-Bond ditunjukkan oleh nilai uji $m 1$ dan $m 2$, yakni nilai uji pada order 1 dan 2. Dimana hipotesisnya adalah sebagai berikut:

Ho : Tidak terdapat autokorelasi antar residual pada first difference orde ke-i

$\mathrm{Hi}$ : Terdapat autokorelasi pada residual first difference orde ke -i

$$
\begin{aligned}
& m_{1}=\frac{\Delta \hat{\varepsilon}_{j, t-1}^{\prime} \Delta \hat{\varepsilon}_{*}^{\prime}}{(\Delta \widehat{\varepsilon})^{1 / 2}} \sim N(0,1) \\
& m_{2}=\frac{\Delta \hat{\varepsilon}_{j, t-2}^{\prime} \Delta \hat{\varepsilon}_{*}^{\prime}}{(\Delta \widehat{\varepsilon})^{1 / 2}} \sim N(0,1)
\end{aligned}
$$

Konsistensi ini ditunjukkan oleh nilai statistik $m 1$ yang signifikan dan nilai statistik $m 2$ yang tidak signifikan.

Kedua, melakukan pengujian untuk mengetahui validasi variabel instrumen yang digunakan melalui uji Sargan yang jumlahnya 
melebihi dari jumlah parameter yang diestimasi (kondisi overidentifying restriction). Dengan uji Sargan, variabel instrumen dikatakan valid apabila tidak ada korelasi lagi dengan error.

Sehingga hipotesis nol untuk uji Sargan menyatakan bahwa tiada ada masalah validasi instrumen dengan artian bahwa variabel instrumen pada kondisi overidentifying tersebut tidak berkorelasi dengan error pada persamaan AB-GMM atau bersifat homoskedastisitas. Namun alternatif dari pengujian uji Sargan dapat dilakukan dengan merubah standar error menjadi robust ${ }^{2}$. Dengan kondisi tersebut model sudah bersifat homoskedastisitas. Pada penelitian ini tidak dapat dilakukan uji Sargan karena model sudah bersifat homoskedastisitas.

Adapun secara ringkas tahapan untuk menduga parameter model data panel dinamis pada pada penelitian ini adalah sebagai berikut:

(1) Melakukan estimasi menggunakan AB-GMM pada kondisi standar error robust. (2) Menguji spesifikasi parameter dengan menggunakan uji Arellano-Bond. (3) Jika tidak memenuhi, maka akan dilanjutkan dengan melakukan estimasi dengan SYS-GMM dengan pada kondisi standar error robust. (4) Menguji spesifikasi parameter dengan menggunakan uji Arellano-Bond. (5) Menguji spesifikasi parameter model dengan

\footnotetext{
${ }^{2}$ Berdasarkan http://www.stata.com/manuals13/rgmmpostestimation.pd f
}

secara bersama-sama dengan menggunakan uji Wald. (6) Menguji signifikansi parameter model secara partial menggunakan uji $\mathrm{Z}$ serta tanda dari setiap koefisien estimasi yang diperoleh akan dianalisis untuk melihat relevansinya dengan teori. (7) Memeriksa apakah estimator yang dihasilkan berada diantara nilai koefisien lag dependen pooled least squares (PLS) dan fixed effects model (FEM). (8) Kemudian dari hasil estimasi juga akan dilakukan analisis untuk menjawab tujuan dan hipotesis penelitian.

\section{HASIL DAN PEMBAHASAN}

Statistik deskripsi yang dihimpun untuk mengestimasi dampak ekspektasi harga gabah dan volatilitas gabah terhadap alokasi luas lahan tanam padi disajikan pada Tabel 5.2. Luas lahan tanam padi diukur dalam hektar dan rata-rata luas tanam per kabupaten 10,1 ribu hektar sedangkan rata-rata lahan sawah yang tersedia 31,64 ribu hektar atau sekitar 30,94\% dari luas total lahan sawah. Fluktuasi luas lahan tanam padi antar waktu dan antar kabupaten bervariasi cukup tinggi dengan nilai koefisien variasi sebesar $88,79 \%$. Hal ini mengimplikasikan bahwa perubahan alokasi lahan tanam padi sepanjang musim tanam cukup tinggi. Sementara itu ratarata luas lahan tanam jagung per kabupaten 3,4 ribu hektar. Fluktuasi luas lahan tanam jagung antar waktu dan antar kabupaten bervariasi tinggi sebesar $162 \%$. 
Tabel 1. Statistik Deskriptif Data Sampel Penelitian

\begin{tabular}{llrrr}
\hline Variabel & Satuan & \multicolumn{1}{c}{ Mean } & Std. Dev. & CV $(\%)$ \\
\hline Luas lahan tanam padi $^{1}$ & $\mathrm{Ha}$ & $10.100,5800$ & $8.968,8300$ & 79,0256 \\
Luas lahan tanam jagung $^{1}$ & $\mathrm{Ha}$ & $3.444,2100$ & $5.613,6000$ & 88,7952 \\
Ekspektasi harga gabah $^{2}$ & $\mathrm{Rp} / \mathrm{Kg}$ & $3.648,6520$ & 712,0946 & 162,9866 \\
Volatilitas harga gabah $^{2}$ & $\%$ & 9,9781 & 6,2027 & 19,5166 \\
Volatilitas harga jagung $^{2}$ & $\%$ & 9,4297 & 7,8595 & 62,1636 \\
Ekspektasi harga jagung $^{2}$ & $\mathrm{Rp} / \mathrm{Kg}$ & $3.079,2240$ & 798,6499 & 83,3479 \\
Harga Pupuk Urea $^{3}$ & $\mathrm{Rp} / \mathrm{Kg}$ & $1.760,0000$ & 80,0224 & 25,9367 \\
Harga Upah Tenaga Kerja $^{4}$ & $\mathrm{Rp} / \mathrm{Kg}$ & $32.832,0600$ & $9.579,2830$ & 4,5467 \\
Harga Benih Padi $^{3}$ & $\mathrm{Rp} / \mathrm{Kg}$ & $3.542,0000$ & $1.488,6440$ & 29,1766 \\
Jumlah penduduk $^{4}$ & $\mathrm{Jiwa}$ & 506,2878 & 477,5993 & 42,0283 \\
Luas Lahan Sawah $^{5}$ & $\mathrm{Ha}$ & $32.640,1600$ & $20.409,5200$ & 94,3336 \\
\hline
\end{tabular}

Sumber : Berbagai sumber (Diolah)

1. Data TP, Kementan-BPS

2. Data BPS dan Data BKP

3. Permentan HET Pupuk dan Benih

4. Statistik Upah Buruh Tani dan Statistik Kependudukan, BPS dan

5. Statitik Lahan Pertanian, Basis Data Pusdatin-Kementan

Metode estimasi SYS-GMM telah memenuhi kriteria model terbaik untuk alokasi lahan tanam padi dan jagung. Nilai probabilitas hasil uji Arrelano Bond menunjukkan $m_{1}$ signifikan sedangkan $m_{2}$ tidak signifikasi baik untuk alokasi lahan tanam padi maupun jagung. Dengan kata lain kedua metode estimasi baik dengan ABGMM maupun SYS GMM konsisten untuk kedua komoditas tersebut. Namun dari uji Wald menunjukkan bahwa metode SYS-GMM lebih signifikan dibandingkan dengan metode estimasi AB-GMM, tingkat probabilitas model SYS-GMM lebih kecil dibandingkan dengan AB-GMM. Begitu juga dilihat dari besaran estimator SYSGMM lag dependen menunjukkan berada diantara nilai koefisien pooled least squares (PLS) dan fixed effects model (FEM).

Tabel 2. Hasil Estimasi Alokasi Luas Tanam Padi

\begin{tabular}{lcccccccc}
\hline Variabel & \multicolumn{6}{l}{ Variabel dependen : Alokasi Luas Tanam Padi } \\
\cline { 2 - 8 } & Pool & \multicolumn{1}{l}{ FE } & & AB-GMM & \multicolumn{3}{c}{ SYS-GMM } \\
\hline Ln $\mathrm{A}_{\mathrm{t}-1}$ & 0,6719 & $* * *$ & $-0,0972$ & $* * *$ & 0,1959 & $*$ & 0,1933 & $* *$ \\
& 0,0000 & & 0,0001 & & 0,2130 & & 0,032 & \\
Ln E $\left(\mathrm{p}_{1}\right)$ & 0,4181 & $* * *$ & 0,2771 & $* * *$ & 0,2341 & $* *$ & 0,2504 & $* *$ \\
& 0,0000 & & 0,0020 & & 0,0370 & & 0,0210 & \\
Volgbh & $-0,0063$ & $* * *$ & $-0,0047$ & $* *$ & $-0,0048$ & $*$ & $-0,0051$ & $* * *$ \\
& 0,0003 & & 0,0300 & & 0,0999 & & 0,0580 & \\
Ln E $\left(\mathrm{p}_{2}\right)$ & $-0,0432$ & & 0,0792 & & $-0,0110$ & & 0,0092 &
\end{tabular}




\begin{tabular}{|c|c|c|c|c|c|c|c|c|}
\hline \multirow[t]{2}{*}{ Variabel } & \multicolumn{8}{|c|}{ Variabel dependen : Alokasi Luas Tanam Padi } \\
\hline & \multicolumn{2}{|l|}{ Pool } & \multicolumn{2}{|c|}{ FE } & \multicolumn{2}{|c|}{ AB-GMM } & \multicolumn{2}{|c|}{ SYS-GMM } \\
\hline & 0,4230 & & 0,2640 & & 0,8888 & & 0,902 & \\
\hline \multirow[t]{2}{*}{ Voljgg } & 0,0081 & $* * *$ & 0,0047 & *** & 0,0049 & $* * *$ & 0,0049 & $* * *$ \\
\hline & 0,0000 & & 0,0100 & & 0,0020 & & 0,0020 & \\
\hline \multirow[t]{2}{*}{ Ln Uph } & $-0,1969$ & $* * *$ & $-0,3511$ & & $-0,2950$ & & $-0,2840$ & \\
\hline & 0,0004 & & 0,3030 & & 0,3550 & & 0,2860 & \\
\hline \multirow[t]{2}{*}{ Ln TT } & 0,2423 & $* * *$ & 0,2906 & * & 0,1210 & & 0,3903 & $* * *$ \\
\hline & 0,0000 & & 0,0690 & & 0,7120 & & 0,0790 & \\
\hline \multirow[t]{2}{*}{ Ln Pddk } & 0,0036 & & $-0,1779$ & * & $-0,1439$ & $* *$ & $-0,1375$ & \\
\hline & 0,8150 & & 0,0910 & & 0,0170 & & 0,1020 & \\
\hline \multirow[t]{2}{*}{ Ln Hpp } & 0,2113 & & 0,5753 & & 0,3981 & & 0,3980 & \\
\hline & 0,4530 & & 0,2150 & & 0,3110 & & 0,2490 & \\
\hline \multirow[t]{2}{*}{ Ln Benih } & 0,0547 & & $-0,0439$ & & $-0,0118$ & & $-0,0104$ & \\
\hline & 0,1010 & & 0,2670 & & 0,7120 & & 0,7190 & \\
\hline \multirow[t]{2}{*}{ Konstanta } & $-2,7756$ & & 4,1747 & * & 4,8163 & & 1,6485 & \\
\hline & 0,1750 & & 0,0820 & & 0,1999 & & 0,5410 & \\
\hline
\end{tabular}

$*, * *, * * *$, signifikan pada level $1 \%, 5 \%, 10 \%$

Tabel 3. Hasil Estimasi Alokasi Luas Tanam Jagung

\begin{tabular}{|c|c|c|c|c|c|c|c|}
\hline \multirow{3}{*}{$\begin{array}{l}\text { Variabel } \\
\text { Ln } A_{t-1}\end{array}$} & \multicolumn{7}{|c|}{ Variabel dependen : Luas Alokasi Tanam Jagung } \\
\hline & \multicolumn{2}{|c|}{ Pool } & \multicolumn{2}{|c|}{ FE } & \multirow{2}{*}{$\begin{array}{l}\text { AB-GMM } \\
-0,0379\end{array}$} & \multicolumn{2}{|c|}{ SYS-GMM } \\
\hline & 0,8540 & *** & 0,0109 & & & 0,3849 & \\
\hline & 0,0000 & & 0,6490 & & 0,4410 & 0,0000 & \\
\hline \multirow[t]{2}{*}{$\operatorname{Ln} \mathrm{E}\left(\mathrm{p}_{1}\right)$} & 0,0015 & & $-0,0518$ & & 0,0449 & 0,0978 & \\
\hline & 0.9910 & & 0,6870 & & 0,7000 & 0,5700 & \\
\hline \multirow[t]{2}{*}{ Volgbh } & 0,000097 & & 0,0014 & & 0,0280 & 0,0014 & \\
\hline & 0,9980 & & 0,6000 & & 0,3460 & 0,761 & \\
\hline \multirow[t]{2}{*}{$\operatorname{Ln} \mathrm{E}\left(\mathrm{p}_{2}\right)$} & $-0,0094$ & & 0,2623 & & 0,1542 & 0,5020 & * \\
\hline & 0,935 & & 0,0910 & * & 0,3960 & 0,0750 & \\
\hline \multirow[t]{2}{*}{ Voljgg } & $-0,0027$ & & $-0,0047$ & * & $-0,0038$ & $-0,0062$ & \\
\hline & 0,3490 & & 0,0660 & & 0,1760 & 01620 & \\
\hline \multirow[t]{2}{*}{ Ln Uph } & $-0,3991$ & & 0,0286 & & 0,3463 & $-0,3817$ & \\
\hline & 0,004 & & 0,9330 & & 0,3280 & 0,4540 & \\
\hline \multirow[t]{2}{*}{ Ln TT } & 0,0534 & $* *$ & 0,2269 & & 0,4213 & 1,2549 & $* *$ \\
\hline & 0,1890 & & 0,4910 & & 0,3630 & 0,0350 & \\
\hline \multirow[t]{2}{*}{ Ln Pddk } & 0,0431 & & -02717 & * & $-0,2086$ & 0,3283 & \\
\hline & 0,1350 & & 0,0680 & & 0,2370 & 0,2540 & \\
\hline \multirow[t]{2}{*}{ Ln Hpp } & 0,6936 & & 0,6857 & & $-0,0492$ & 0,5757 & \\
\hline & 0,137 & & 0,2060 & & 0,9120 & 0,4140 & \\
\hline Ln Benih & 0,2127 & ** & 0,0609 & & 0,0656 & 0,0420 & \\
\hline
\end{tabular}




\begin{tabular}{lcrcr}
\hline \multirow{2}{*}{ Variabel } & \multicolumn{4}{l}{ Variabel dependen : Luas Alokasi Tanam Jagung } \\
\cline { 2 - 5 } & Pool & FE & AB-GMM & SYS-GMM \\
\hline \multirow{3}{*}{ Konstanta } & 0,002 & 0,1890 & 0,0720 & 0,4580 \\
& $-2,8052$ & $-1,8599$ & $-1,1451$ & 16,119 \\
& 0,4070 & 0,6710 & 0,8380 & $0,016 \quad * *$ \\
\hline
\end{tabular}

Tabel 2 dan Tabel 3 memperlihatkan dampak ekspektasi harga output berdasarkan metode estimasi SYS-GMM untuk alokasi lahan tanam padi dan jagung. Hasilnya menunjukkan bahwa ekspektasi harga gabah berdampak positif terhadap alokasi luas tanam padi pada tingkat signifikan 5\%. Begitu juga dengan ekspektasi harga jagung yang berdampak positif terhadap alokasi lahan tanam jagung pada tingkat signifikan $10 \%$. Kedua model alokasi lahan tanam dalam penelitian ini merespon secara positip dan signifikan terhadap perubahan ekspektasi harga output sendiri (own price). Kondisi ini konsisten dengan konseptual teori Coyle (1992) yang menjelaskan secara teoritis bahwa kenaikan ekspektasi harga output dapat meningkatkan alokasi tanam. Kondisi ini juga sejalan juga dengan studi empiris yang telah dilakukan sebelumnya diantaranya oleh Adesina \& Wade Brosen (1987); Chavas \& Holt (1990); Krause \& Koo (1996); Leo S.A, 2000;Haille, Kalkuhl, \& Braun $(2013,2015)$.

Alokasi lahan tanam padi merespon lebih kecil perubahan ekspektasi harga gabah dibandingkan dengan respon alokasi lahan tanam jagung terhadap perubahan ekpektasi harga jagung. Hal ini dapat dilihat dari nilai koefisien regresi untuk ekspektasi harga gabah lebih kecil dibandingkan dengan nilai koefisien regresi untuk ekspektasi harga jagung untuk setiap alokasi lahan tanam masing-masing komoditas. Dimana pada kondisi variabel independen lain konstan, kenaikan ekspektasi harga gabah sebesar $1 \%$ dapat meningkatkan alokasi lahan tanam padi sebesar 0,25\% sedangkan kenaikan ekspektasi harga jagung dapat meningkatkan alokasi lahan tanam jagung sebesar $0,50 \%$.

Tidak seperti halnya ekspektasi harga output sendiri (own price), volatilitas harga output sendiri (own volatility price) baik gabah dan jagung menunjukkan dampak yang berbeda terhadap alokasi lahan tanam. Volatilitas harga gabah dan jagung lebih berdampak pada perubahan alokasi lahan tanam padi dibandingkan dengan alokasi lahan tanam jagung. Dimana setiap kenaikan 1\% standar deviasi dari perubahan harga gabah dapat mengurangi alokasi lahan tanam padi sebesar 0,0051\% sedangkan kenaikan 1\% standar deviasi dari perubahan harga jagung dapat meningkatkan alokasi lahan tanam padi sebesar $0,0049 \%$. Kondisi ini sesuai dengan teori yang telah dikemukakan sebelumnya bahwa produser dalam hal ini petani yang bersifat risk averse akan mengurangi alokasi sumber daya produksi dan meningkatkan alokasi sumber daya produksi komoditas subtitusinya (Sandmo, 1971; Batra \& Ullah, 1974; Coyle, 1992). Namun pada penelitian ini tidak menunjukkan cukup bukti bahwa volatilitas harga gabah dan jagung dapat memberikan dampak terhadap alokasi lahan tanam jagung. Perubahan alokasi lahan tanam jagung tidak responsif terhadap perubahan volatilitas harga gabah maupun volatilitas harga jagung.

Lag alokasi tanam satu periode sebelumnya secara statistik memberikan dampak positif terhadap model alokasi lahan tanam baik komoditas padi ataupun jagung. Kondisi ini sejalan dengan hasil penelitian Haille, Kalkuhl, \& 
Braun (2013,2015) yang berdampak positif terhadap alokasi tanam. Menurut Haille, Kalkuhl, \& Braun (2015), koefisien regresi dari lag alokasi tanam satu periode sebelumnya mengindikasikan bahwa terjadi biaya penyesuaian (cost adjustment) akibat dari rotasi jenis komoditas dari padi ke jagung atau sebaliknya atau penyesuaian dari input produksi yang relatif tetap ${ }^{3}$. Sementara itu Hausman (2012) menjelaskan bahwa koefisien lag dependen merefleksikan variabel diluar model yang tidak teramati (unobserved dynamics faktors).

Harga input produksi merupakan faktor penting yang dapat mempengaruhi keputusan petani dalam menentukan alokasi lahan tanam padi maupun jagung. Secara teori ekonomi kenaikan input harga produksi dapat mempengaruhi penurunan produksi, produktivitas dan alokasi lahan tanam. Namun dalam penelitian ini kedua jenis input produksi yaitu upah buruh tani, benih padi inbrida dan benih jagung komposit tidak membuktikan adanya dampak terhadap alokasi lahan tanam padi dan jagung. Hal ini diduga dari penggunaan data upah buruh tani yang digunakan dalam penelitian ini menggunakan data provinsi yang variasinya relatif kecil sehingga tidak terlalu merefleksikan harga upah buruh tani tingkat kabupaten. Sementara itu data harga input benih yang digunakan merupakan harga benih subsidi yang harganya relatif rendah dan stabil.

Pada penelitian ini kepadatan penduduk di setiap kabupaten/kota mempengaruhi alokasi lahan tanam padi. Dimana setiap peningkatan kepadatan penduduk sebesar $1 \%$ dapat menurunkan alokasi lahan tanam padi sebesar $0,1375 \%$ pada kondisi variabel independen lain konstan. Hal ini terjadi karena kepadatan

\footnotetext{
${ }^{3}$ Misalnya sepesifik lahan, tingkat kesuburan tanah ataupun teknologi.
}

penduduk merupakan gambaran pertumbuhan jumlah penduduk dan pengembangan perdesaan terhadap sejumlah lahan. Dengan demikian peningkatan kepadatan penduduk dapat meningkatkan permintaan lahan untuk berbagai kebutuhan penduduk seperti tempat tinggal dan tidak menutup kemungkinan akan terjadi alih lahan fungsi dari pertanian ke nonpertanian.

Sementara itu penambahan areal lahan sawah terbukti memberikan dampak positif terhadap alokasi tanam padi dan jagung. Kondisi ini konsisten dengan adanya kebijakan pemerintah dalam meningkatkan produksi melalui perluasan areal sawah sejak tahun 2011 diberbagai wilayah di Indonesia. Dengan adanya penambahan areal sawah baru tersebut mendorong alokasi tanam padi dan jagung menjadi lebih tinggi. Dimana setiap kenaikan 1\% luas lahan sawah dapat meningkatkan alokasi lahan tanam padi sebesar $0,3980 \%$ dan $12,549 \%$ alokasi lahan jagung dimana variabel yang lain relatif konstan. Hal ini sesuai dengan kondisi yang ada di lapanngan, pembentukan areal sawah baru yang akan digunakan untuk padi memerlukan waktu yang lebih panjang dibandingkan dengan jagung.

Pada penelitian ini kebijakan stabilisasi harga gabah melalui HPP tidak cukup bukti memberikan dampak positif terhadap alokasi tanam padi. Temuan ini tidak sejalan dengan penelitian yang dilakukan oleh Chavas \& Holt, 1990 dan Krause \& Koo, $(1995,1996)$ dimana adanya kebijakan harga dapat memberikan dampak yang positip terhadap alokasi lahan atau bahkan tidak terjadi respon yang signifikan terhadap alokasi lahan tanam. Begitu juga dengan studi yang dilakukan oleh Hadi (2000) bahwa perubahan harga dasar Gabah (HGD) akan meningkatan luas lahan padi. Namun hal ini dimungkinkan terjadi karena serapan gabah/beras yang dibeli pemerintah melalui 
Perum BULOG hanya sebagian kecil dari produksi nasional. Selain itu juga sesuai dengan tujuan dari kebijakan dibentuk memang untuk membantu petani meningkatkan harga jual gabah disaat jatuh pada musim panen raya sehingga efektivitas dari kebijakan ini terasa dampaknya ketika harga gabah jatuh pada periode-periode tertentu.

\section{SIMPULAN}

Secara teori ekonomi keputusan petani dalam menanam padi akan dipengaruhi oleh ekspektasi harga dan volatilitas harga gabah yang akan dihasilkan. Petani secara individu mungkin tidak akan mempertimbangkan apakah keputusan menanam atau tidak menanam padi akan mempengaruhi ketersediaan padi di suatu wilayah. Namun tentu tidak demikian bagi pemerintah, pemerintah berkepentingan terhadap penyediaan pangan setiap saat untuk melaksanakan Undang-undang pangan.

Menggunakan data panel kabupaten/kota selama periode tahun 2011-2015, penelitian ini melakukan investigasi dampak ekspektasi dan volatilitas harga padi terhadap alokasi lahan tanam padi di Indonesia. Disamping untuk melihat perubahan alokasi lahan tanam padi, secara simultan penelitian ini juga ingin melihat perubahan alokasi lahan tanam jagung sebagai komoditas subtitusinya. Hasil estimasi menunjukkan bukti bahwa perubahan alokasi luas lahan tanam padi di Indonesia lebih responsif daripada alokasi lahan tanam jagung terhadap volatilitas harga. Perubahan alokasi lahan tanam padi menjadi lahan jagung dapat berubah pada setiap musim tanam padi ketika terjadi perubahan harga gabah ataupun volatilitas gabah. Pengalokasian lahan tanam padi ke lahan tanam jagung tersebut memang tidak terjadi pada saat adanya perubahan harga ekspektasi harga jagung akan tetapi terjadi ketika harga jagung berfluktuasi. Kondisi ini berbeda dengan perubahan alokasi lahan tanam jagung, perubahan alokasi lahan tanam jagung tidak merespon perubahan harga gabah ataupun volatilitas harga gabah. Perubahan lahan tanam jagung hanya merespon terhadap perubahan harga ekspektasi harga jagung saja. Hal ini memang terkait dengan infrastruktur dari lahan sawah untuk padi dapat cepat digunakan untuk jagung akan tetapi tidak berlaku sebaliknya.

Perubahan alokasi tanam padi dapat terjadi pada jangka waktu pendek yaitu pada saat setiap perubahan alokasi tanam. Musim tanam kedua yang terjadi pada bulan Mei sampai dengan Agustus merupakan musim tanam yang terendah dibandingkan dengan musim tanam pertama dan musim tanam ketiga. Hal ini terjadi dikarenakan pada musim tanam kedua sudah memasuki periode musim yang curah hujannya lebih sedikit dibandingkan musim tanam pertama (subround I) ataupun musim tanam ketiga (subround III). Akibatnya hasil panen padi pada musim kedua yang terjadi pada periode September sampai Desember akan lebih rendah dibandingkan musim tanam pertama dan musim ketiga. Dengan demikian kenaikan harga gabah pada akhir tahun akan berlangsung terus jika kondisi masih terjadi pada periode ke depan.

Implikasi kebijakan yang diperlukan berdasarkan hasil studi ini adalah upaya penurunan tingkat volatilitas harga gabah. Fluktuasi luas tanam padi di setiap musim merupakan salah satu penyebab terjadinya volatilitas harga gabah. Untuk itu diperlukan pasokan gabah pada saat penyediaan berkurang. Kebijakan cadangan pangan dapat menjadi solusi untuk mengatasi gejolak harga gabah. Hal ini dapat dilakukan dengan meningkatkan cadangan gabah melalui lumbung padi masyarakat. Lumbung padi masyarakat yang dimaksud adalah menyimpan sebagian hasil panen gabah di saat panen raya dan menjualnya di saat 
penyediaan berkurang yaitu sekitar bulan September sampai Desember. Dengan demikian gejolak harga gabah dapat teratasi. Selain itu penambahan pasokan gabah pada musim tersebut diperlukan peningkatan areal tanam pada musim tanam kedua yang didukung oleh sarana prasarana seperti pengembangan varietas benih padi unggul yang siap dalam menghadapi curah hujan sedikit ataupun gelombang panas.

\section{DAFTAR PUSTAKA}

Abbott, P. C., Hurt, C., \& Teyner, W. E. (2011). What is Driving Food Prices in 2011? Indiana: Farm Foundation.

Adesina, A. A., \& Brorsen, B. W. (1987). A Risk Responsive Acreage Respons Function for Millet in Niger. Agricultural Economic I, 229-239.

Aimin, H. (2010). Uncertainty, Risk Averse and Risk Management in Agriculture. Agriculture and Agricultural Science Procedia , 152-156.

Anderson, T., \& Hsiao, C. (1982). Formulation and Estimation of Dynamic Models Using Panel Data. Journal od Econometris 18(1), 47-82.

Antonovits, F., \& Green, R. (1990). Alternative Estimates of Fed Beef Supply Response to Risk. Agricultural and Apllied Economic Assosiation, Vol.72 No.2.

Arnade, C., \& Kelch, D. R. (2007). Estimation of Area Elasticities from a Standart Profit Function. American Journal of Agricultural Economic .

Arrelano, M., \& Bond, S. (1991). Some Test of Specifications For Panel Data : Monte Carlo Evidence and Applications to
Employments Equations. The Reviews Economics Studies 58(2), 277-279.

Batra, R. N., \& Ullah, A. (1974). Competitive Firm and the Theory of Input Demand Under Price Uncertainty. Journal of Political Economy, 537-548.

Bellemare, M., C. Barret, \& D.Just . (2013). The Welfare Impacts of Commodity Price Volatility : Evidence from Rural Ethiopia . American Journal of Agricultural Economics 95 (4) , 877-99.

Carlos, A., \& Joseph, C. (2013). Price Expectation and Supply Response. Annual Meeting Agricultural and Applied Economics Association. Washington DC.

Chavas, J. P., \& Holt, T. H. (1990). Acreage Dicision Under Risk : The Case of Corn and Soybean. American Journal of Agricutural Economics, Vo. 72, No 3.

Coyle, B. T. (1992). Risk Averse and Price Risk in Duality Model Production: A linear Mean-Variance Approach. Agricultural and Applied Economics Association, 849-859.

Ezekiel, M. (1938). The Cobweb Theorem. The Quartely Journal of Economics, 255-280.

FAO. (2011). Price Volatility in Food and Agricultural Markets : Policy Response.

Fariyanti, A., \& et.al. (2007). Perilaku Ekonomi Rumah Tangga Petani Sayuran Pada Kondisi Risiko Produksi dan Risiko Harga di Kecamatan Pangalengan Kabupaten Bandung. Agro Ekonomi, 178206.

Gardner, B. L. (1976). Futures Prices in Supply Analysis. American Journal of Agricultural Economics , 81-88. 
Gilbert, C. L., \& Morgan, C. W. (2010). Food Price Volatility. Philosophical Transaction of The Royal Society B: Biological Science 365 (1554).

Hadi, P. (2000). Dampak Kebijakan Harga Dasar Pada Harga Produsen, Harga Konsumen dan Luas Tanam Padi: Belajar dari Pengalaman Masa Lalu. Pusat Analisis Ekonomi dan Kebijakan Pertanian.

Haile, M. G., Kalkuhl, M., \& Usman, A. M. (2015). Market Information and Smallholder Farmes Price Expectations. African Journal of Agricultural and Resource Economics, 10(4) : 297-311.

Haille, M. G., Kalkuhl, M., \& Braun, J. V. (2013). Inter-and intra seasonal crop acreage response tointernational food price and implications of volatility. Agricultural economic.

Haille, M. G., Kalkuhl, M., \& Broun, J. V. (2015). Wordwide Acreage and Yield Response To International Price Change And Volatility : A Dynamic Panel Data Analysis For Wheat, Rice, Corn, and Soybean. Amer.J.Agron. 98(1) : 172 -190.

Huchet, M., \& Bourdon. (2011). Agricultural Commodity Price Volatility: An Overview. Paris: OECD Food, Agriculture and Fisheries Makalahs, No. 52, OECD Publishing .

Kementerian Pertanian. (2015). Rencana Strategis Kementerian Pertanian Tahun 2015-2019. Jakarta.

Krause, M. A., Lee, J. H., \& Koo, W. W. (1995). Program and Nonprogram Wheat Acreage Response to Price and Risk. Journal of Agricultural and Resource Economics , 20(1); 96-107.
Krause, M., \& Koo, W. (1996). Acreage Responses to Expected Revenue an Price Risk for Minor Oilseed and Program Crops in The Northern Plains. Journal of Agricultural and Resources Economics, 309-324.

Lansink, A. O. (1999). Area Allocation Under Price Uncertainty an Dutch Arable Farms. Journal od Agricultural Economics , 93-105.

Lin, C. P. (1997). Acreage Response under Price Risk : An Econometric Analysis of Kansas Crop Acreage Decision. Departement of Agricultural Economic. Manhattan, Kansas: Kansas State University.

Miau, R., Khanna, M., \& Huang, H. (2015). Responsiveness of Crop Yield and Acreage to Price and Climate. America Journal Agricultural Economic, 98(1): 191121.

Modelina, A. A., Roe, T. L., \& Shane, M. (2004). Measuring commodity price volatility and the welfare consequences of eliminating volatility. Colorado: AAEA Annual meeting.

Moschini, G., \& Henessy, D. (1999, July). Uncertainty, Risk Aversion, and Risk Management for Agricultural Producers. Amsterdam: Handbook of Agricultural Economics, Vol. 1, Part A, 2001, pp. 87153.

Muth, J. F. (1961). Rational Expectations and the Theory of Price Movements. Journal of Econometrica Society 29(3), 315-335.

Nerlove, M. (1956). Estimates of Elasticities of Supply of Selected Agricultural Commodities. Journal of Farm Economics 38 (2), 496-509.

Nickell, S. (1981). Biases in Dynamic Models with Fixed Effects. Econometrica 49(6), 14171426. 
Orazem , P., \& Minanowski, J. (1994). Dynamic Model of Acreage Allocation. Journal of Agricultural Economics, 385-395.

Sandmo, A. (1971). On The Theory of Competitive Firm Under Price Uncertainty. The American Economic Reviews 61 (1), 65-73.

Shina , A. F., \& Setiawan. (2015). Estimasi Parameter Sistem Model Persamaann Simultan Pada Data Panel Dinamis Dengan GMM Arellano dan Bonnd. Prosiding Seminar Nasional Matematik dan Pendidikan Matematika .

Tedesse, G., Algerie, B., Kalkuhl, M., \& Braun, J. V. (2014). Drivers and Triggers of International Food Price Spikevs and Volatility. Food Policy (47), 117-28. 